\title{
On the presence of Phalacroma rotundatum in the southern Adriatic Sea (Italy)
}

\author{
Carmela Caroppo ${ }^{1, *}$, Roberta Congestri ${ }^{2, * *}$, Milena Bruno $^{2}$ \\ ${ }^{1}$ Institute for the Study of Coastal Ecosystems, Consiglio Nazionale delle Ricerche, Via Pola 4, I-71010 Lesina (FG), Italy \\ ${ }^{2}$ Laboratory of Environmental Hygiene, Istituto Superiore di Sanità, I-00161 Rome, Italy
}

\begin{abstract}
The genus Dinophysis sensu lato is often involved in episodes of Diarrhetic Shellfish Poisoning (DSP) contaminations and human intoxications. To date, several species of this genus have shown toxin production in the laboratory; however, it is likely that many others could have this capability. Phalacroma rotundatum (Claparède \& Lachmann) Kofoid \& Michener, allocated by some authors to the genus Dinophysis, is a non-photosynthetic species, which has the potential to produce okadaic acid and its derivatives DTX-1 and DTX-2. This species was observed for the first time along the southern Adriatic coast of Puglia (Italy) during a 2 yr monitoring program on potentially toxic phytoplankton. $P$. rotundatum dynamics was studied in relation to hydrobiological conditions; its seasonal changes appeared rather independent from chemico-physical factors, but were significantly associated with those of phytoflagellates. A toxicity test (Microtox system) on P. rotundatum cells proved negative
\end{abstract}

KEY WORDS: Phalacroma rotundatum · Phytoflagellates $\cdot$ Hydrobiological factors $\cdot$ DSP · Adriatic Sea

\section{INTRODUCTION}

The repeated occurrences of Diarrhetic Shellfish Poisoning (DSP) mussel contaminations in the last few years (Boni 1992, Honsell et al. 1995) in the northern and middle Adriatic coastal waters have led Italian authorities to promote monitoring programs on potentially toxic phytoplankton along the entire Adriatic coastal belt, to collect information about the possible occurrence and abundance of harmful microalgae. Species of the dinoflagellate genus Dinophysis are considered the main DSP threat in the areas of the northern and middle Adriatic coasts where algal monitoring activities are carried out (Ammazzalorso et al. 1991, Fattorusso et al. 1992, Boni et al. 1993, Della Loggia et al. 1993, Tubaro et al. 1995).

Phalacroma rotundatum (Claparède \& Lachmann) Kofoid \& Michener is a dinophysoid non-photosynthetic species, whose genus name is often considered

\section{Present addresses:}

- Istituto Sperimentale Talassografico, Consiglio Nazionale delle Ricerche, Via Roma 3, I-74100 Taranto, Italy.

E-mail: carmela.caroppo@istta.le.cnr.it

- - Department of Biology, University of Rome 'Tor Vergata',

Via della Ricerca Scientifica, I-00133 Rome, Italy synonymous with Dinophysis (Abé 1967, Balech 1967 in Hallegraeff \& Lucas 1988), but recently Hallegraeff $\&$ Lucas (1988) have supported the original generic distinction between Dinophysis and Phalacroma genera, based on physiological and ecological arguments. The morphological features separating the 2 genera: development and direction of the cingular lists in combination with the height and shape of epitheca, have been coupled with the presence or absence of chloroplasts and relative distribution (Dinophysis, mostly neritic and photosynthetic, and Phalacroma, mostly oceanic and heterotrophic), but there are several exceptions: e.g. D. schuettii and D. hastata, non-photosynthetic and $P$. rapa, autotrophic species $\{$ Uallegraeff \& Lucas 1988, Steidinger \& Tangen 1997). In addition, the highly variable chloroplast properties and the phagotrophic potential found in several photosynthetic Dinophysis species (Jacobson \& Andersen 1994) still prevent a clearcut separation between the two and partially support the conclusion of Schnepf \& Elbrächter (1988, in Jacobson \& Andersen 1994) that the entire dinophysoid lineage is fundamentally heterotrophic and apochlorotic.

Phalacroma rotundatum exhibits food vacuoles in its cytoplasm (Hallegraeff \& Lucas 1988, Jacobson \& An- 
dersen 1994, Giacobbe 1995) which have been shown by electron microscopy to contain plastids, with internal pyrenoids, and rare prasinophyte scales (Jacobson \& Andersen 1994). This heterotrophic species has been observed to feed upon prostomatid (Tiarina fusus, Hansen 1991), tintinnid and oligotrich ciliates (Jacobson \& Andersen 1994). Hansen (1991) directly described its feeding behaviour via a peduncle (myzocytosis, Schnepf \& Deichgraber 1983) extending from the flagellar pore, which fuses to the membrane of the prey and sucks on its cytoplasm.

Production of toxins of the okadaic acid group was detected in cells of Phalacroma rotundatum from Japanese waters by Lee et al. (1989) and in the Ria Pontevedra (NW Spain) populations by Blanco et al. (1995), whilst Cembella (1989) and Masselin et al. (1992) considered the populations from eastern coasts of North America and from French coasts, respectively, to be non-toxic. Probably these controversial results are due to regional and temporal factors affecting the toxigenicity of cells of the same species together with the lack of cultures (Blanco et al. 1995, Giacobbe 1995). In Italy, $P$. rotundatum was detected along the northern Adriatic coasts (Boni et al. 1993, Della Loggia et al. 1993, Sidari et al. 1995, Tubaro et al. 1995), along the Ionian coasts of Calabria (Giacobbe et al. 1993, Giacobbe 1995), and in the Strait of Messina (southern Tyrrhenian Sea, Giacobbe 1995).

The present paper reports on a survey on potentially toxic phytoplankton carried out from April 1995 to March 1997 in the southern Adriatic Sea. Phalacroma rotundatum, besides several other potentially toxic algal species (Caroppo et al. 1996), was detected during the sampling period. The dynamics of this species was studied in relation to hydrobiological conditions to contribute to knowledge of the distribution of harmful phytoplankton in the Mediterranean Sea.

In order to investigate the possibility of toxin production by the southern Adriatic populations of Phalacroma rotundatum, raw and sorted samples were tested on bioassay for the presence of okadaic acid.

\section{STUDY AREA}

Whereas the plankton of the northern Adriatic Sea has been much studied, only limited information is available for the southern part, specially with regard to the Italian coasts (Fanuko 1983/84, Marano \& Rizzi 1985, Vilicic et al. 1995).

The southern basin of the Adriatic Sea, the deepest of the 3 Adriatic basins, is hydrologically important as it represents the transition zone of different waters: those coming from the northern Adriatic Sea (Adriatic
Surface Water, ASW) and those of the Ionian Sea (Levantine Intermediate Water, LIW) (Buljan \& ZoreArmanda 1976). Ionian water originates in the Levantine Sea; in wintertime the low temperature $\left(15^{\circ} \mathrm{C}\right)$ and high salinity $(39.1 \%$ ) produce water with a high density that sinks and spreads at intermediate depths (200 to $600 \mathrm{~m}$ ) and invades the southern Adriatic basin, between 40 and $150 \mathrm{~m}$ in depth (Magazzù pers. comm.j. The gradient of density formed between the Adriatic (ASW) and the Ionian water (LIW) produces a circulation which moves southwards along the western coast in summer, and northwards along the eastern coast in winter. In spring and autumn the inflow and outflow intensities are similar (Zore-Armanda 1968).

The analyzed waters are essentially oligotrophic with reference to their inorganic nitrogen $\left(\mathrm{NH}_{4}{ }^{+}+\right.$ $\left.\mathrm{NO}_{2}{ }^{-}+\mathrm{NO}_{3}{ }^{-}\right)-\mathrm{N}$ and phosphorus $\left(\mathrm{PO}_{4}{ }^{3-}-\mathrm{P}\right)$ content, with averaged values of 0.9 and $0.1 \mathrm{\mu g} \mathrm{l}^{-1}$ respectively (Cardellicchio pers. comrn.). The Ionian flow seems to be the major nutrient supply to the surface waters of the southern basin (Buljan et al. 1975, Cescon \& Scarazzato 1979). The annual trend of the temperature in these waters is sinusoidal with wide variations between the winter minimum $\left(8\right.$ to $\left.10^{\circ} \mathrm{C}\right)$ and the summer maximum ( 28 to $29^{\circ} \mathrm{C}$ ) (Marano pers. comm.). The dissolved oxygen shows an inverse sinusoidal trend to the thermal one, varying between 6.27 and $8.54 \mathrm{mg} \mathrm{l}^{-1}$. The surface values often show marked oversaturation, while the rest of the water column does not fall below $84 \%$ (Bregant et al. 1992, 1994). Chlorophyll a (chl a) values are consistently below $0.5 \mu \mathrm{g} \mathrm{t}^{-1}$ and rates of primary production lower than $1 \mu \mathrm{g} \mathrm{Cl}^{-1} \mathrm{~h}^{-1}$ (Faganeli et al. 1989).

The coastal tract under investigation is tall and characterized by the presence of limestone sediments from the Mesozoic (Brambati 1992) and by the lack of remarkable waterways.

\section{MATERIALS AND METHODS}

Monthly samples were collected at 4 stations located $0.5 \mathrm{~km}$ (Stn 1), $3 \mathrm{~km}$ (Stn 2), $5 \mathrm{~km}$ (Stn 3) and $10 \mathrm{~km}$ (Stn 4) from the coast, along 1 transects: (a) Brindisi; (b) S. Cataldo; (c) Otranto and (d) Santa Maria di Leuca (Fig. 1). Samples were taken at 4 discrete depths $(0,5$, 10,20 or $50 \mathrm{~m}$, total depth allowing) at each station, using a 51 Niskin bottle.

Transparency was measured by Secchi disk. Temperature, salinity, dissolved oxygen and $\mathrm{pH}$ were recorded by an Idronaut Ocean Seven 501 multiprobe and compared to in situ (electronic thermometers) and laboratory (Guildline salt-metre, Autosal 8400 B, Winkler and pH-metre) measurements. Nutrient analyses 
$\left(\mathrm{NH}_{4}{ }^{+}-\mathrm{N}, \mathrm{NO}_{2}{ }^{-}-\mathrm{N}, \mathrm{NO}_{3}{ }^{-}-\mathrm{N}, \mathrm{PO}_{4}{ }^{3-}-\mathrm{P}, \mathrm{SiO}_{4}{ }^{2-}-\mathrm{Si}\right)$ were estimated according to Strickland \& Parsons (1972); chl a was determined by the Parsons et al. method (1984).

Phytoplankton analyses were performed on 50 to $100 \mathrm{ml}$ subsamples, preserved with Lugol's iodine solution, allowed to settle for 24 to $48 \mathrm{~h}$ and examined for phytoplankton and Phalacroma cell counts (Utermöhl 1958), using an inverted light microscope at $200 \times$ and $400 \times$ magnification. For species identification, the principal taxonomic texts were those indicated in Zingone et al. (1990). Algae which could not be identified either to the species or the genus level were counted as: small $(<10 \mu \mathrm{m})$ and large $(>10 \mu \mathrm{m})$ phytoflagellates, small $(<15 \mu \mathrm{m})$ and large $(>15 \mu \mathrm{m})$ naked or thecate dinoflagellates. A distinction between photosynthetic and non-photosynthetic species was made using the information available in the literature (Chrétiennot-Dinet 1990, Larsen \& Sournia 1991). Phalacroma identification was based on: Dodge (1982), Rampi \& Bernhard (1980), Sournia (1986), Steidinger \& Tangen (1997), Schiller (1931-33), Taylor et al. (1995). Correlation coefficients between hydrobiological data and Phalacroma cell concentration were computed and significance was tested by the Student's $t$-test.

The toxicity of the species was tested as follows: a $10 \mathrm{mg}$ aliquot of centrifuged fresh algae, obtained by concentrating the bottle sample showing the highest Phalacroma rotundatum density ( 1460 cells $\left.~^{-1}\right)$, was extracted with $1 \mathrm{ml} \mathrm{MeOH} 90 \%$. In addition, 650 cells of $P$. rotundatum were picked up from a net sample, harvested in April 1998 by repeated vertical net tows (20 $\mathrm{mm}$ mesh), and extracted as above. The solution was stirred, sonicated $\left(5 \mathrm{~min}\right.$ at 30 to $40^{\circ} \mathrm{C}$ ), then centrifuged and the supernatant collected. The extraction was repeated on the cell pellet; the resulting supernatants were pooled and tested using the Microtox system (Microbics, Inc.).

The bacterial bioassay Microtox system is based on 4 progressive dilutions of the extracted sample which are put in contact with equal concentrations of the phosphorescent marine bacterium Vibrio fisheri. The presence of toxins in the sample gives a diminution in the lightening of the microrganisms, and the values read by luminometer of the system, statistically processed by a software computer program in a trend with confidence limits, give the extinction coefficient value at $50 \%$ of the bacterial lightening. The system was tested in the laboratory with various algal toxins, among which was okadaic acid (Gucci et al. 1989, Bruno et al.1990, Bruno et al. 1994).

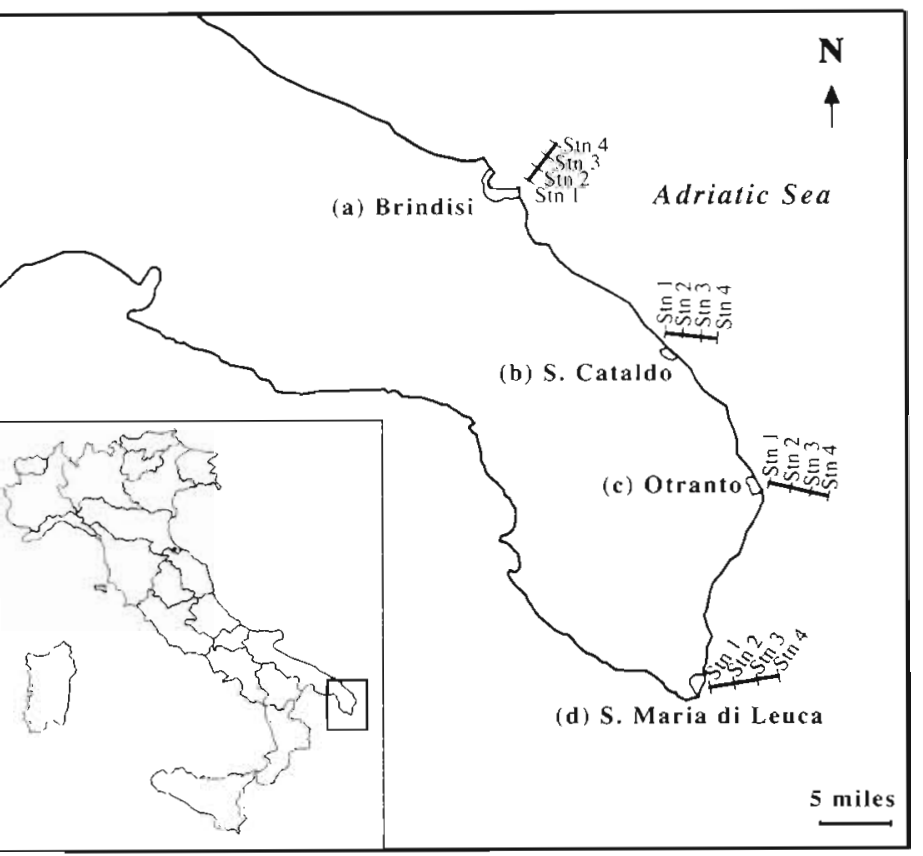

Fig. 1. Map of the study area with sampling stations and transects

\section{RESULTS}

\section{Phalacroma rotundatum densities}

Phalacroma rotundatum (Claparède \& Lachmann) Kofoid \& Michener was recorded for the first time in these southern Adriatic waters. It occurred over the whole sampling area, mainly in the autumn-winter months, at moderate densities. Light microscopic observations of specimens revealed cells round-oval in shape, 45 to $53 \mu \mathrm{m}$ in width and 45 to $55 \mu \mathrm{m}$ in length, with laterally visible, domed, epitheca and, occasionally, with large globules in the cytoplasm that could be interpreted as food vacuoles (Fig. 2a,b).

Phalacroma rotundatum seasonal appearence was characterized by slight fluctuations in the entire area with abundances ranging from 160 cells $^{-1}$ (S. Cataldo and Otranto, inner stations, surface layer, July 1995) to

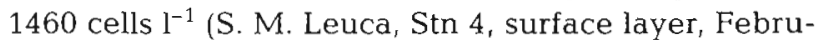
ary 1997). Annual distribution of $P$. rotundatum densities was similar in the 2 yr of survey.

Maximal densities were observed within the 0 to $10 \mathrm{~m}$ depth layer, but vertical cell segregation was not marked (Fig. 3). Distance from the coastline appeared to slightly affect the distribution of cells, which occurred more frequently at the outer stations, especially during the first year of the survey (Fig. 4). The highest frequencies were observed along the southern transects of Otranto and S. M. Leuca.

In spring Phalacroma rotundatum occurred sporadically along the transects of S. Cataldo, Otranto and S. 

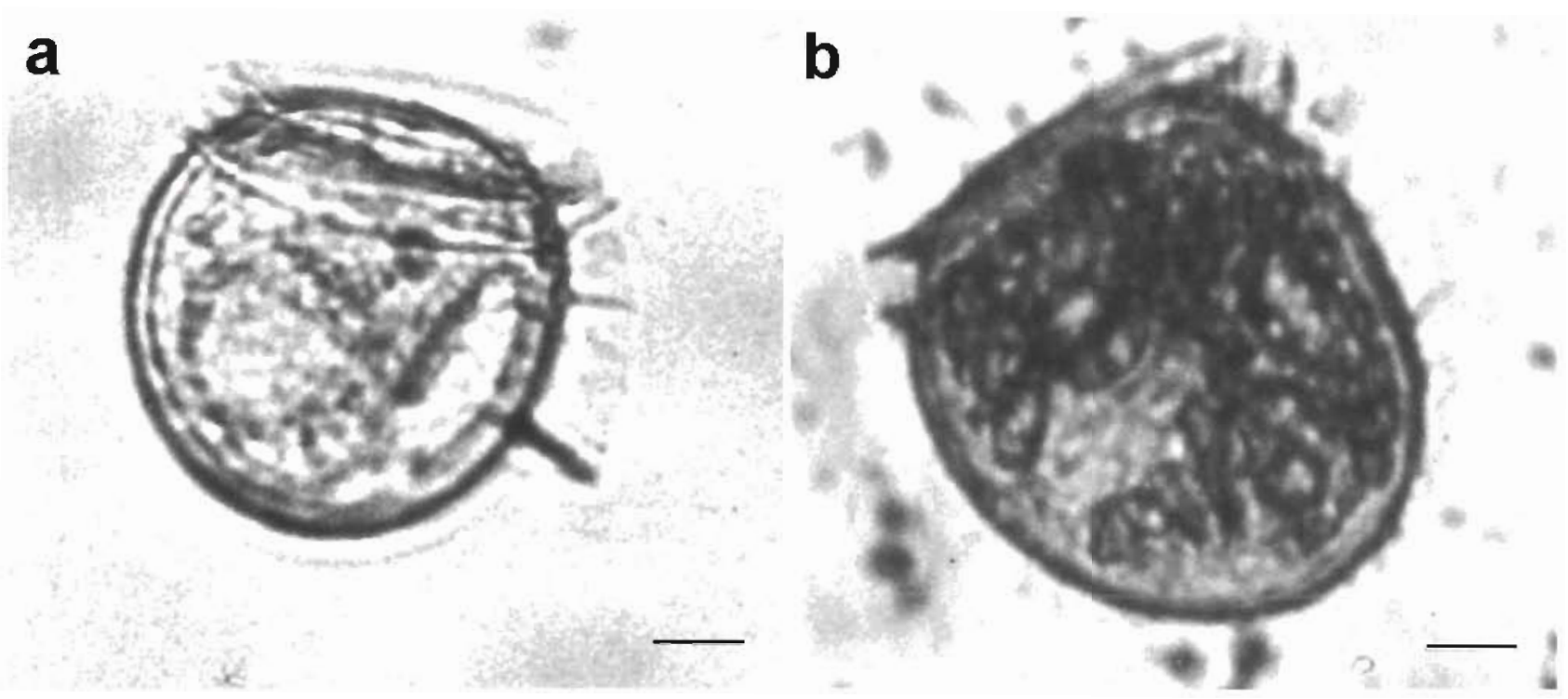

Fig. 2. Phalacroma rotundatum. (a) Cell from the sampling area. (b) Cell containing food vacuole-like globules. Scale bars $=10$ um
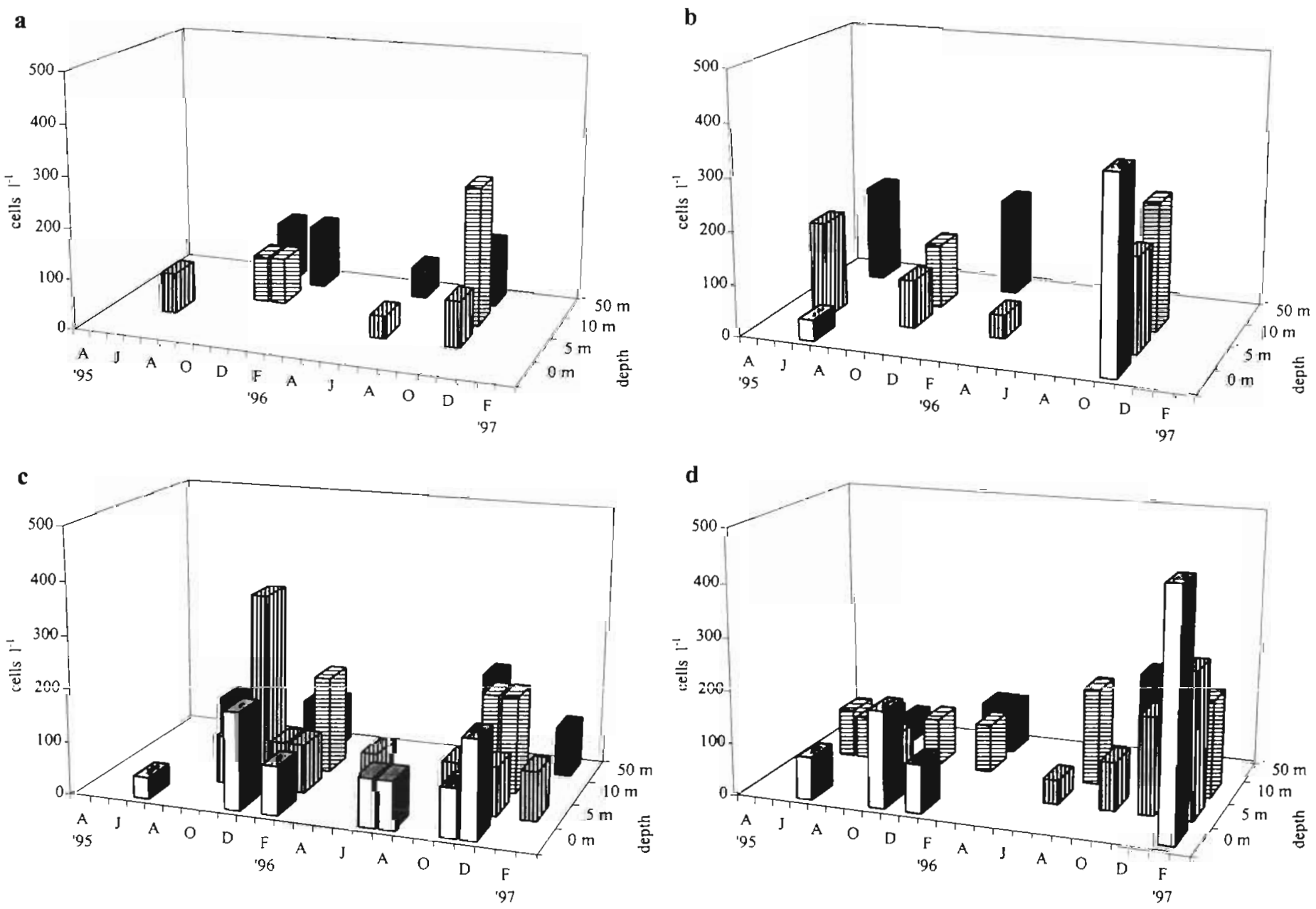

Fig. 3. Phalacroma rotundatum. Monthly variations of average concentrations at each depth of the examined stations and transects. (a) Brindisi, (b) S. Cataldo, (c) Otranto, (d) S. M. Leuca 
M. Leuca except in May, when it was not detected at any stations. At $\mathrm{S}$. Cataldo, this species was present mainly at the outer stations, with densities ranging

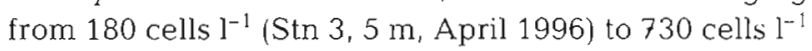
(Stn 4, $5 \mathrm{~m}$, June 1995), whereas along Otranto and S. $M$. Leuca transects it was recorded once only, with the abundance of 365 cells $^{-1}$, at Stns 4 (5 m, June 1996) and 2 (10 m, June 1995), respectively.

During the summer period, there was a general increase in cell numbers, more evident at Otranto and S. M. Leuca, although abundances were maintained at

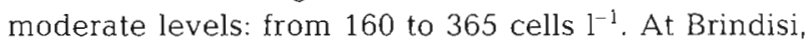
Phalacroma rotundatum was observed at Stns 1, 2 and 4, always in July, at depths of $5 \mathrm{~m}$ (up to 320 cells $\mathrm{l}^{-1}$. Stn 1,1995$)$ and $50 \mathrm{~m}$ (180 cells $\left.\mathrm{l}^{-1}, \mathrm{Stn} 4,1996\right)$. The only report of $P$. rotundatum along $\mathrm{S}$. Cataldo was in July 1995 at $\operatorname{Stn} 1\left(0 \mathrm{~m}, 160\right.$ cells $\left.\mathrm{l}^{-1}\right)$. In the southern areas a wider distribution of this dinoflagellate was observed. At Otranto $P$, rotundatum showed the highest concentrations within the surface layer (up to 365 cells $1^{-1}$, July and August 1996) and was also recorded once at $50 \mathrm{~m}$ (320 cells $1^{-1}$. Stn 3, July 1995). At S. M. Leuca it occurred at all depths, with maximal densities at $10 \mathrm{~m}$. In September $P$. rotundatum was not recorded at any sampling sites.

In autumn, this species was observed with higher frequencies at all transects, stations and depths, especially in November. Along Brindisi and S. Cataldo transects Phalacroma rotundatum was detected mainly in November, when the maximum values $\left(730\right.$ cells $1^{-1}$, Stn 1, $10 \mathrm{~m}, 1996)$ were reached. At Otranto and S. M. Leuca this species occurred in similar densities and more frequently.

In winter, frequencies declined at the northern transects where Phalacroma rotundatum occurred once only, in January and February 1995 respectively, both
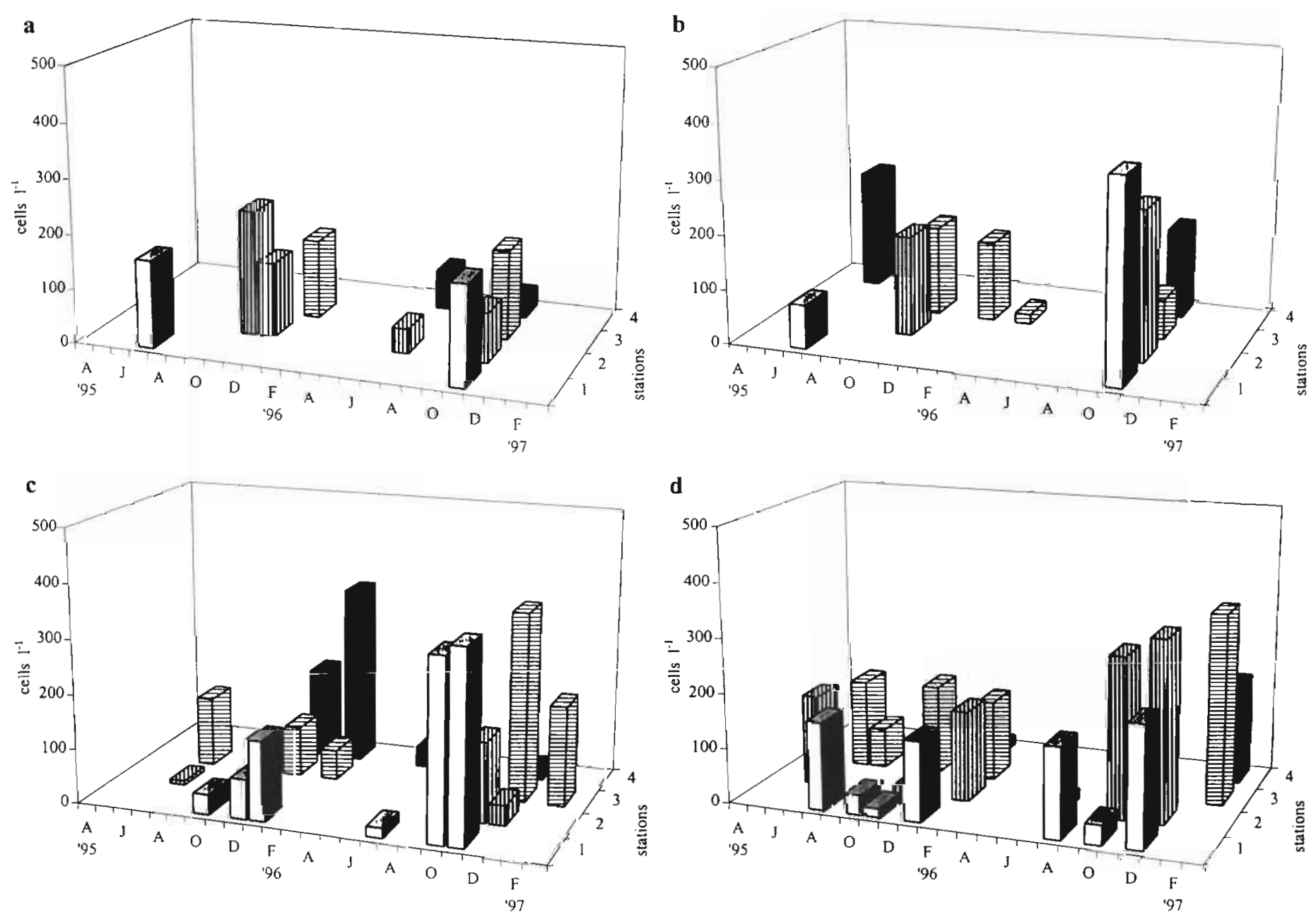

Fig. 4. Phalacroma rotundatum. Monthly variations of average concentrations at each station of the examined transects. (a) Brindisi, (b) S. Cataldo, (c) Otranto, (d) S. M. Leuca. The values are reported as 0 to 50 m integrated values 


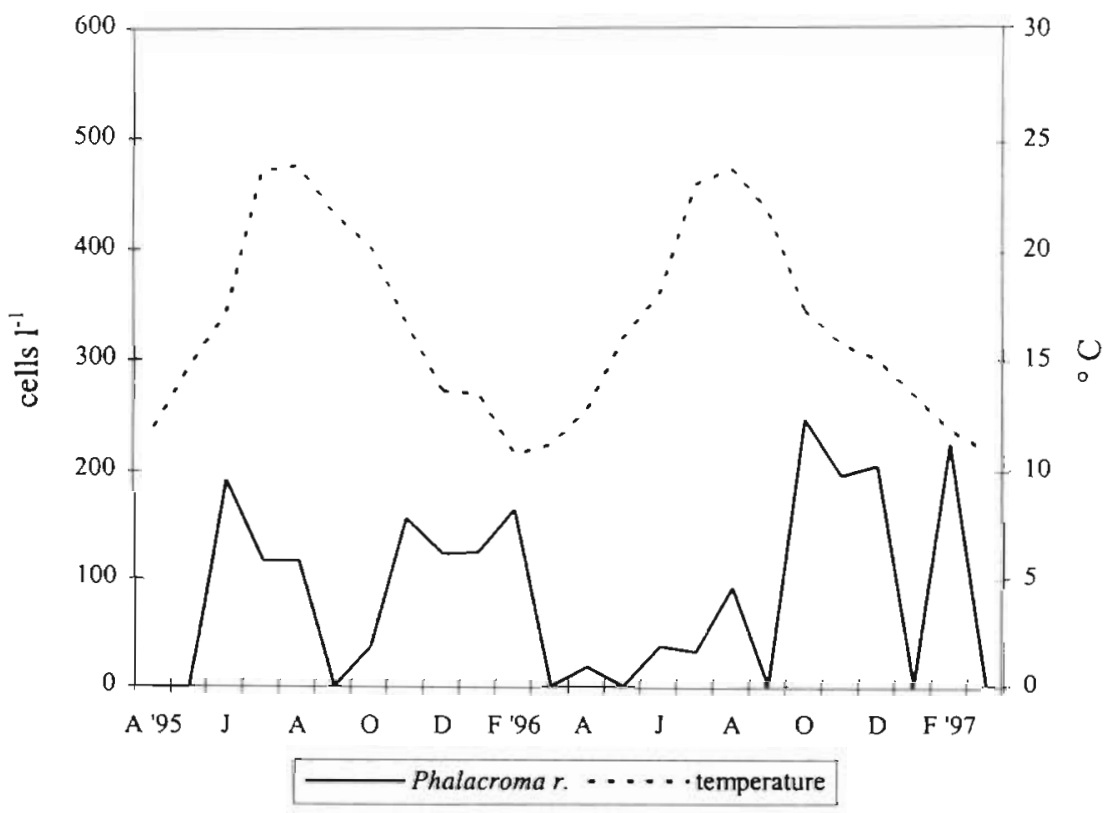

Fig. 5. Phalacroma rotundatum. Temporal trends of densities and water temperature averaged for all stations and transects

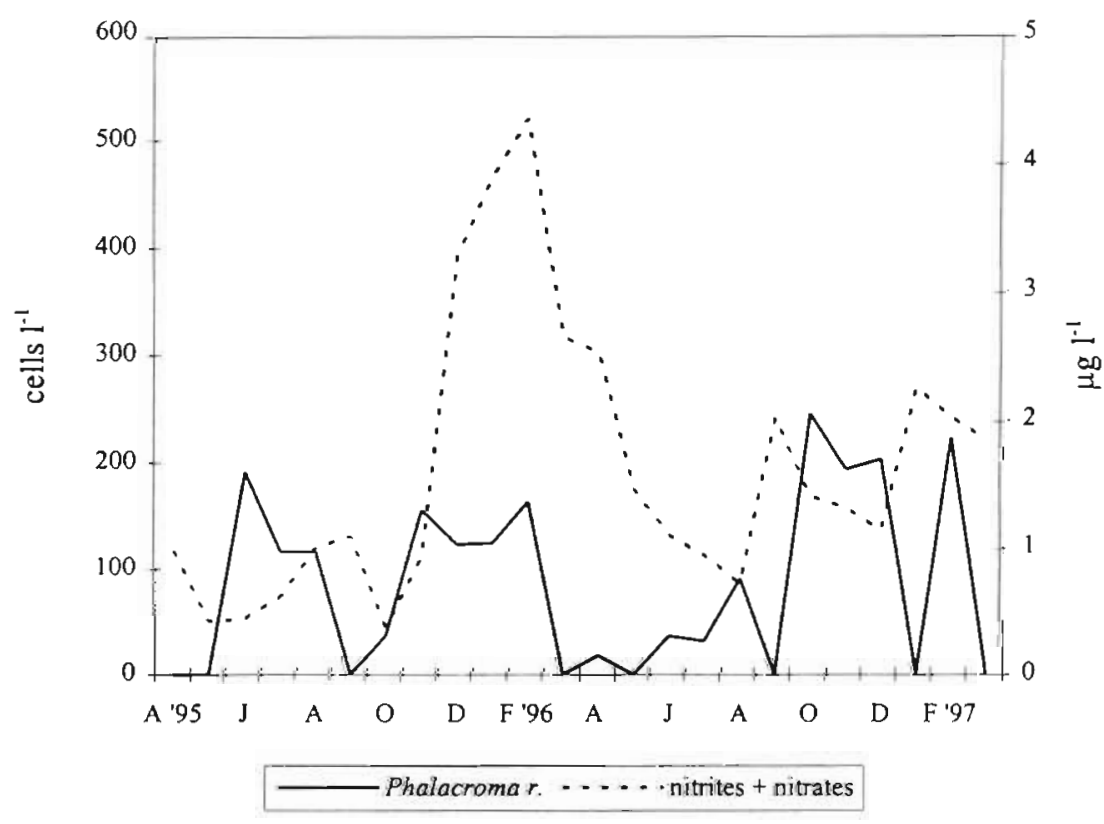

Fig. 5. Phalacroma rotundatum. Temporal rends of densities and $N$ (nitrite + nitrate) concentration averaged for all stations and transects at S. M. Leuca (Stn 4, 0 m, 1997). Then, in March, this species disappeared throughout the water column.

The Microtox assay gave negative results.

\section{Abiotic and biotic factors}

The average temperature had a seasonal cycle characterized by a minimum of $10.2^{\circ} \mathrm{C}$ in February and a maximum of $26.9^{\circ} \mathrm{C}$ in July. Water warming began in May, with temperature over $16^{\circ} \mathrm{C}$, and peaked in JulyAugust, when a sharp thermocline was established. Water stratification came to an end in November, with thermal homogeneity throughout the column, then in winter (January and February), when the cold ASW prevailed for its move southwards, a thermal inversion, particularly detectable along Brindisi and S. Cataldo transects, was observed again. At the southern transects this thermal inversion occurred with higher temperature values $\left(13.8^{\circ} \mathrm{C}\right)$ probably due to the ingression of the LIW (Fiocca et al. 1998). Salinity reached minimal values (36.9 to $37.7 \%$ ) in winter. Dissolved oxygen ranged from $98.7 \%$ (January 1996) to $129.7 \%$ (December 1996).

$\mathrm{N}$ and $\mathrm{P}$ distribution and concentration were widely influenced by the global circulation in the basin and the higher values were reached in winter: $\mathrm{NO}_{2}{ }^{-} \mathrm{N}$ and $\mathrm{NO}_{3}{ }^{-}-\mathrm{N}$ reached their maximum levels, of 1.35 (February) and $4.27 \mathrm{\mu g}^{-1}$ (January) respectively, at Otranto in 1996. $\mathrm{NH}_{4}{ }^{+}-\mathrm{N}$ was present at very low concentrations, ranging between 0.01 and $0.84 \mu \mathrm{g} \mathrm{l}^{-1}(\mathrm{~S}$. Cataldo, August 1995), without significant fluctuations throughout the year. Also $\mathrm{PO}_{4}{ }^{3-}$ - $\mathrm{P}$ levels were low, at times undetectable, and quite constant, with

with the abundance of 365 cells $1^{-1}$ and at the same station and depth (Stn 3,50 m), whereas at Otranto and S. $M$. Leuca this species was present at all the sampling stations and depths with significant densities. The highest annual densities, both during the first and second year of the study, were observed in February: 730

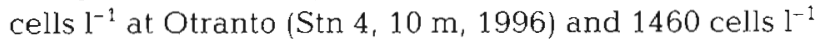
average values below $0.1 \mu \mathrm{gl}^{-1}$. In the winter months the highest $\mathrm{SiO}_{4}{ }^{2-}$-Si concentrations were detected too, which ranged from $0.31 \mu \mathrm{g} \mathrm{l}^{-1}$ (Otranto, October 1996) to $7.23 \mu \mathrm{g} \mathrm{l}^{-1}$ (S. M. Leuca, January 1996).

Phalacroma rotundatum appeared rather independent from thermal conditions as supported by correlation analysis (Table 1) and the only correlation be- 
Table 1. Phalacroma rotundatum. Correlation coefficients and Student's t-test for dependent samples between densities and hydrobiological data

\begin{tabular}{|c|c|c|c|c|c|c|c|c|c|c|c|c|c|c|c|c|}
\hline & \multicolumn{4}{|c|}{ (a) Brindisi } & \multicolumn{4}{|c|}{ (b) S. Cataldo } & \multicolumn{4}{|c|}{ (c) Otranto } & \multicolumn{4}{|c|}{ (d) S. M. Leuca } \\
\hline & $\mathrm{r}$ & $\mathrm{p}$ & $t$ & $\mathrm{p}$ & $r$ & $\mathrm{p}$ & $t$ & $\mathrm{p}$ & $\mathrm{r}$ & $\mathrm{p}$ & $t$ & $\mathrm{p}$ & $\mathrm{r}$ & $\mathrm{p}$ & $t$ & $\mathrm{p}$ \\
\hline Temperature & -0.26 & ns & -5.35 & $<0.01$ & 0.09 & ns & -3.15 & $<0.05$ & -0.58 & ns & -3.79 & $<0.01$ & -0.57 & ns & -5.13 & $<0.01$ \\
\hline Nitrites + nitrates & -0.60 & ns & -6.16 & $<0.01$ & 0.01 & ns & -4.31 & $<0.01$ & 0.38 & ns & -4.42 & $<0.01$ & 0.13 & $\mathrm{~ns}$ & -5.95 & $<10^{-4}$ \\
\hline Chlorophyll a & 0.20 & ns & -6.25 & $<0.01$ & 0.68 & ns & -4.35 & $<0.01$ & 0.76 & $<0.05$ & -4.45 & $<0.01$ & 0.65 & $<0.05$ & -6.00 & $<10^{-4}$ \\
\hline Diatoms & 0.33 & ns & 3.17 & $<0.05$ & -0.10 & ns & 1.32 & ns & 0.30 & ns & 2.38 & $<0.05$ & -0.17 & ns & 3.78 & $<0.01$ \\
\hline Dinoflagellates & -0.05 & ns & 4.25 & $<0.01$ & -0.41 & ns & 1.83 & ns & 0.23 & ns & 2.01 & ns & 0.12 & ns & 3.81 & $<0.01$ \\
\hline Coccolithophorids & -0.35 & ns & 2.79 & $<0.05$ & -0.74 & ns & 2.25 & ns & 0.13 & ns & 3.06 & $<0.05$ & 0.48 & ns & 7.15 & $<10^{-4}$ \\
\hline Small phytoflagellates & 0.96 & $<0.05$ & 4.73 & $<0.01$ & 0.80 & $<0.05$ & 5.40 & $<0.01$ & 0.69 & $<0.05$ & 14.64 & $<10^{-4}$ & 0.54 & ns & 7.32 & $<10^{-4}$ \\
\hline Large phytoflagellates & 0.58 & ns & 3.38 & $<0.05$ & 0.41 & ns & 3.30 & $<0.05$ & -0.41 & ns & 4.47 & $<0.01$ & -0.19 & ns & 3.70 & $<0.01$ \\
\hline Total phytoflagellates & 0.90 & $<0.05$ & 4.93 & $<0.01$ & 0.56 & ns & 5.87 & $<0.01$ & 0.10 & ns & 16.39 & $<10^{-4}$ & 0.69 & $<0.05$ & 2.38 & $<0.05$ \\
\hline Phytoplankton & 0.52 & ns & 4.38 & $<0.01$ & -0.34 & ns & 1.86 & ns & 0.29 & ns & 3.36 & $<0.01$ & -0.01 & ns & 7.84 & $<10^{-4}$ \\
\hline
\end{tabular}

tween nutrient $\left(\mathrm{NO}_{2}{ }^{-}-\mathrm{N}+\mathrm{NO}_{3}{ }^{-}-\mathrm{N}\right)$ dynamics and Phalacroma was found along the Otranto transect during the second year of sampling $(r=-0.756, p<$ $0.05 ; t=-2.976, \mathrm{p}<0.05) . \mathrm{PO}_{4}{ }^{3-}$ - $\mathrm{P}$ was not considered in the analysis for its low and constant levels during the investigation, which did not permit any hypothesis as to its role in the dynamics of this species. In Figs. $5 \& 6$ the trends of $P$. rotundatum, temperature and $\mathrm{NO}_{2}{ }^{-}-\mathrm{N}+\mathrm{NO}_{3}{ }^{-} \mathrm{N}$ are represented, averaged for all transects.

Phytoplankton biomass (chl a) was correlated to phytoplankton densities ( $\mathrm{r}=0.59, \mathrm{p}<0.05 ; t=-4.63, \mathrm{p}<0.01$ ) and was quite low, with mean values ranging from a minimum of $0.05 \mu \mathrm{g} \mathrm{I}^{-1}$ (S. M. Leuca, July 1995) to a maximum of $1.25 \mathrm{\mu g} \mathrm{l}^{-1}$ (S. Cataldo, January 1997); chl a concentration showed a seasonal trend with the highest values in winter (Fig. 7), more limited for S. M. Leuca transect (max value, $0.65 \mu \mathrm{g} \mathrm{I}^{-1}$, January 1997). Phalacroma was significantly correlated to phytoplankton biomass along the southern transects (Otranto and S. M. Leuca) (Table 1).

Average phytoplankton densities showed generally low values, within $1 \times 10^{5}$ cells $1^{-1}$, with the exception of winter levels in both years of investigation when, during the yearly blooming, average values of $3.3 \times 10^{5}$ cells $\mathrm{l}^{-1}$ (February 1995) and $10.4 \times 10^{5}$ cells $\mathrm{l}^{-1}$ (January 1997) were recorded.

As to quality, diatoms represented the larger component in the population $(44.3 \%)$ together with phytoflagellates $(39.6 \%)$; dinoflagellates and coccolithophorids, on the other hand, accounted for 10.3 and $5.8 \%$ respectively. During the year diatoms were dominant with high cell densities in the autumn-winter period, phytoflagellates had a larger distribution over time and their average values varied between 4 and $55 \times$ $10^{3}$ cells $\mathrm{l}^{-1}$. They were mainly represented by small $(68.5 \%)$ and large $(17.8 \%)$ forms of uncertain taxonomic classification and cryptophyceans (8.3\%), whereas the 'others' (prasino-, chryso-, euglenophyceans and silicoflagellates) accounted for only $5.4 \%$. Phytoflagellates reached the minimum percentage at Brindisi $(36.1 \%)$ against S. Cataldo $(38.8 \%)$, Otranto $(40.9 \%)$ and S. M. Leuca (43.6\%) transects. In particular, at Brindisi, they were observed mainly in spring $(41.4 \%)$ and autumn months $(44.8 \%)$ while in the other transects they were detected mainly in summer (S. M. Leuca, $56.8 \%$; Otranto, $53.7 \%$; S. Cataldo, $49.5 \%$ ). 


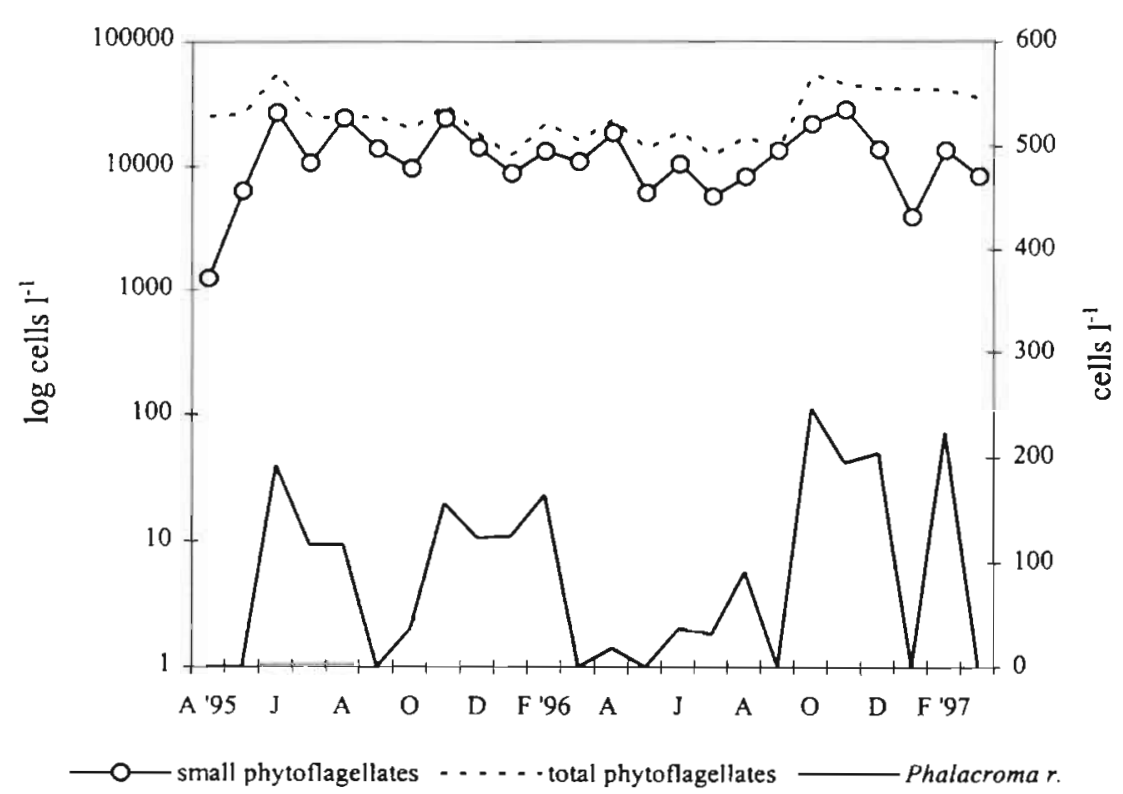

Fig. 8. Temporal trends of total phytoflagellates and small phytoflagellates (log scale) and Phalacroma rotundatum densities averaged for all stations and transects

Phalacroma rotundatum seasonal variations were significantly correlated with those of phytoflagellates, specially with the small form ones. This feature was evidenced analyzing spatially pooled distributional data (Fig. 8) and, more in detail, considering the correlation coefficients between the spatio-temporal patterns of $P$. rotundatum and those of phytoflagellate populations at the individual sampling transects (Table 1).

\section{DISCUSSION}

The seasonal occurrence of Phalacroma rotundatum in the southern Adriatic basin was similar in the 2 different years of the survey, showing a rather wide temporal distribution in both cases, although in low numeric densities. Thus this species seemed to show a certain adaptability to environmental variations throughout the year, as observed by Sidari et al. (1995) in the Gulf of Trieste (NTW Adriatic Sea). On that orrasion, $P$. rotundatum maximum abundances and frequencies were detected in spring, whereas in the southern Adriatic this dinoflagellate has occurred in the autumn-winter months. Both these findings could suggest a preference of $P$. rotundatum for conditions of high turbulence and active water mixing. This latter aspect could also explain the more frequent observations of $P$. rotundatum in the winter period along the more southerly transects, where a greater incidence of LIW would contribute to the development of denser populations of this species, different from northern transects where the effects of ASW seem to prevail

Particularly interesting was the association of Phalacroma rotundatum with the phytoflagellate assemblage, mainly with the nanoplanktonic component. The almost overlapping distributional patterns of this species and those of phytoflagellates seemed to go beyond a simple simultaneous fluctuation in the phytoplankton community. Although no experimental evidence yet exists to support a trophic link between this heterotrophic dinophysoid and phytoflagellates, a similar coincidence in the temporal cycles of Dinophysis spp. and Tiarina fusus was evidenced by Hansen (1991) when describing Dinophysis rotundata predation upon that prostomatid ciliate. It is known that phagocytosis of ciliates and other protists by marine dinoflagellates is a widespread phenomenon, both among heterotrophic (aplastidic) and mixotrophic (photosynthetic) taxa (Jacobson \& Anderson 1996) which can, through a more or less selective mechanism (Jacobson \& Anderson 1986), complicate the food webs in plankton communities. Further studies are needed to elucidate growth requirements of $P$. rotundatum and the role played by the phytoflagellates on its population dynamics.

The negative results of the Microtox bioassay, both on raw and sorted samples of the southern Adriatic Phalacroma rotundatum populations agree with the findings of Cembella (1989) and Masselin et al. (1992), but are contrary to those of Lee et al. (1989) and Blanco et al. (1995), indicating that further assays are needed to clarify the toxin production of this species and the possible relationships with its heterotrophic metabolism and spatio/temporal variations.

Acknowledgements. We are indebted to Prof. G. Magazzù (deceased August 18, 1998), who kindly supplied physicochemical data obtained in the Hydrobiology Laboratory of Lecce University. This work was supported by the Ministry of University and Scientific and Technological Research, within. the framework of the 'Adriatic Sea Safeguard' project.

\section{LITERATURE CITED}

Ammazzalorso P, Ercolessi M, Giorgi G, Trotta I, De Rosa F, Grassini P (1991) Indagine sulla presenza di Dinophysis e tossina liposolubile DSP in molluschj ed acque di mare adibite alla molluschicoltura in provincia di Pesaro, nell'estate 1990. Ig Mod 96(2):142-172 
Blanco J, Fernandez M, Marino J, Reguera B, Miguez A, Maneiro J "Cacho E, Martinez A (1995) From Dinophysis spp. toxicity to DSP outbreaks: a preliminary model of toxin accumulation in mussels. In: Lassus P, Arzul G, Erard E, Gentien P, Marcaillou C (eds) Harmful marine algal blooms. Lavoisier, Paris, p 777-782

Boni L (1992) Toxic marine phytoplankton in Italy. G Bot Ital 126(2):229-236

Boni L, Milandri A, Poletti R, Pompei M (1993) DSP cases along the coast of Emilia-Romagna (Northwestern Adriatic sea). In: Smayda TJ, Shimizu Y (eds) Toxic phytoplankton blooms in the sea. Elsevier, Amsterdam, p $475-481$

Brambati A (1992) The Adriatic Sea: origin and evolution. In Colombo G, Ferrari I, Ceccherelli VU, Rossi R (eds) Marine eutrophication and population dynamics. Olsen and Olsen Publ, Fredensborg, p 327-346

Bregant D, Allegra A, Azzaro F, Civitarese G, Crisafi E, La Ferla R, Lucchetta A, Rabitti S (1992) Condizioni idrologiche dell'Adriatico Meridionale. Aprile 1990. Proceedings of the IX Congress of the Italian Association of Oceanography and Limnology. Genod, p 25-33

Bregant D, Azzaro F, Bonaccorso A, Civitarese $G$, Crisafi $E$, La Ferla R, Leonardi M, Lucchetta A, Polimeni R, Raicich F (1994) Condizioni idrologiche dell'Adriatico meridionale. Novembre 1991. Proceedings of the $X$ Congress of the Italian Association of Oceanography and Limnology. Genoa, p 37-46

Bruno M, Gucci PMB, Pierdominici E, Ioppolo A, Volterra L (1990) Presence of saxitoxin in toxic extracts from Gonyaulax polyedra. Toxicon 28(9):1113-1116

Bruno M, Barbini DA, Pierdominici E, Serse AP, Ioppolo A (1994) Anatoxin-a and a previously unknown toxin in Anabaena planctonica from blooms in lake Mulargia (Italy). Toxicon 32(3):369-373

Buljan M, Zore-Armanda M (1976) Oceanographic properties of the Adriatic Sea. Oceanogr Mar Biol Annu Rev 14: $11-98$

Buljan M, Stojanoski L, Vukadin I (1975) Distribution of nutrient salts in waters of the middle and the southern Adriatic Sea. Thalassia Jugosl 11:139-149

Caroppo C, Congestri R, Buzzelli E, Bruno M (1996) The genus Dinophysis in the Southern Adriatic Sea. G Bot Ital 130(4-6): 1065-1068

Cembella AD (1989) Occurrence of okadaic acid, a major diarrheic shellfish toxin, in natural populations of Dinophysis spp. from the eastern coast of North America. J Appl Phycol 1:307-310

Cescon B, Scarazzato P (1979) Hydrological features of the Adriatic Sea during winter and spring. Chemical observations. Boll Geofis Applic 21:14-37

Chrétiennot-Dinet MJ (1990) Chlorarachniophycées, Chlorophycées, Chrysophycées, Chryptophycées, Euglénophycées, Eustigmatophycćes, Prasinophycées, Prymnesiophycées, Rhodophycées et Tribophycées. In: Sournia A (ed) Atlas du phytoplancton marin. Editions CNRS, Paris

Della Loggia R, Cabrini M, Del Negro P, Honsell G, Tubaro A (1993) Relationship between Dinophysis spp. in seawater and DSP toxins in mussels in the northern Adriatic sea. In: Smayda TJ, Shimizu Y (eds) Toxic phytoplankton blooms in the sea. Elsevier, Amsterdam, p 483-488

Dodge JD (1982) Marine dinoflagellates of the British Isles. HMSO, London, p 1-310

Faganeli J, Gacic M, Malej A, Smodlaka N (1989) Pelagic inorganic matter in the Adriatic Sea in relation to winter hydrographic conditions. J Plankton Res 11(6):1129-1141

Fanuko N (1983/84) Il fitoplancton dell'Adriatico nel gennaio
1980. Nova Thalassia $6: 31-36$

Fattorusso E, Ciminiello P, Costantino V, Magno S, Mangoni A, Milandri A, Poletti R, Pompei M, Viviani R (1992) Okadaic acid in mussels of Adriatic sea. Mar Pollut Bull $24(5): 234-237$

Fiocca A, Sambati A, Sammarco P, Marra P, Magazzù G (1998) Monitoring of the environmental conditions in the Adriatic coast of Salento, 1995-'97 Physico-chemical parameters and nutrient salts. Biol Mar Medit 5:620-626

Giacobbe MG (1995) Morphological observations on Dinophysis species (Dinophyceae) from Mediterranean coastal waters. Cryptogam Algol 16 (4):233-245

Giacobbe MG, Greco S, Maimone G (1993) Distribuzione di Dinoflagellate potenzialmente tossiche o dannose nelle acque calabresi. Biol Mar Medit 1:49-53

Gucci PMB, Bruno M, Volterra L (1989) Rilevamento di biotossine algali con il test Microtox. Inquinamento 11:79-81

Hallegraeff GM, Lucas IAN (1988) The marine dinoflagellate genus Dinophysis (Dinophyceae): photosynthetic, neritic and non-photosynthetic, oceanic species. Phycologia 27 (1): $25-42$

Hansen PJ (1991) Dinophysis - a planktonic dinoflagellate genus which can act both as a prey and a predator of a ciliate. Mar Ecol Prog Ser 69:201-204

Honsell G, Nichetto P, Sidari L, Tubaro A (1995) Toxic dinoflagellates in the Mediterranean sea. G Bot Ital 129:391-403

Jacobson DM, Andersen R A (1994) The discovery of mixotrophy in photosynthetic species of Dinophysis (Dinophyceae): light and electron microscopical observations of food vacuoles in Dinophysis acuminata, $D$. norvegica and two heterotrophic dinophysoid dinoflagellates. Phycologia 33(2):97-110

Jacobson DM, Anderson DM (1986) Thecate heterotrophic dinoflagellates: feeding behavior and mechanisms. J Phycol 22:249-258

Jacobson DM, Anderson DM (1996) Widespread phagocytosis of ciliates and other protists by marine mixotrophic and heterotrophic thecate dinoflagellates. J Phycol 32:279-285

Larsen J, Sournia A (1991) The diversity of heterotrophic dinoflagellates. In: Larsen J, Patterson DJ (eds) The biology of free-living heterotrophic flagellates. Systematics Association Spec Vol 45, Clarendon Press, Oxford, p $313-332$

Lee JS, Igarashi T, Fraga S, Dahl E, Hovgaard P, Yasumoto T (1989) Determination of diarrhetic shellfish toxins in various dinoflagellate species. J Appl Phycol 1:147-152

Marano G, Rizzi E (1985) Fitoplancton del litorale pugliese. Campagna 1984. Nova Thalassia 7(3):423

Masselin P, Lassus P, Bardouil M (1992) High performance liquid chromatography analysis of diarrhetic toxins in Dinophysis spp. from the French coast. J Appl Phycol 4 385-389

Mengarelli C, Bucci D, Bruno M, Gucci PMB, Volterra L (199i) Difficoltà di rilevamento di Dinophysis tossiche. Ig Mod 96(2):200-207

Parsons TR, Maita Y, Lalli CM (1984) A manual of chemical and biological methods for seawater analysis. Pergamon Press, Oxford, p 1-173

Rampi L, Bernhard M (1980) Chiave per la determinazione delle Peridinee pelagiche Mediterranee. CNEN, Rome (RT/B10(80)8)

Schiller J (1931-1933) Dinoflagellateae. Rabenhorst's Kriptogamen Flora Teil 1, Vol 10(3). Akademische Verlag, Leipzig, p 1-617

Schnepf E, Deichgraber G (1983) 'Myzocytosis', a kind of endocytosis with implications to comportamentation in endosymbiosis. Observations in Paulsenella (Dinophyta). 
Naturwissenschaften 71:218-219

Sidari L, Cok S, Cabrini M, Tubaro A, Honsell G (1995) Temporal distribution of toxic phytoplankton in the Gulf of Trieste (Northern Adriatic sea) in 1991 and 1992. In: Lassus P, Arzul G, Erard E, Gentien P, Marcaillou C (eds) Harmful marine algal blooms. Lavoisier, Paris, p 231-236

Sournia A (1986) Cyanophycées, Dictyochophycées, Dinophycées, Raphidophycéees. In: Sournia A (ed) Atlas du phytoplancton marin. Edition du CNRS, Paris, p $1-219$

Steidinger KA, Tangen K (1997) Dinoflagellates, In: Tomas $C R$ (ed) Identifying marine phytoplankton. Academic Press, New York, p 387-584

Strickland YDH, Parsons TR (1972) A practical handbook of seawater analysis. Bull Fish Res Board Can 167:1-311

Taylor FJR, Fukuyo Y, Larsen J (1995) Taxonomy of harmful dinoflagellates. In: Hallegraeff GM, Anderson DM, Cembella $A D$ (eds) Manual on harmful marine microalgae.

Editorial responsibility: Patricia Glibert,

Cambridge, iviaryland, USA
IOC manuals and guides no. 33, UNESCO, Paris, p 283-317

Tubaro A, Sosa S, Bussani D, Sidari L, Honsell G, Della Loggia $R$ (1995) Diarrhoeic toxicity induction in mussels of the Gulf of Trieste. In: Lassus P, Arzul G, Erard E, Gentien P, Marcaillou $C$ (eds) Harmful marine algal blooms. Lavoisier, Paris, p 249-254

Utermöhl H (1958) Zur Vervollkommnung der quantitativen Phytoplankton-Methodik. Mitt Int Ver Theor Angew Limnol 9:1-38

Vilicic D, Leder N, Grzetic Z, Jasprica N (1995) Microphytoplankton in the Strait of Otranto (Eastern Mediterranean). Mar Biol 123:619-630

Zingone A, Honsell G, Marino D, Montresor M, Socal G (1990) Fitoplancton. In: Innamorati M, Marino D, Ferrari I, Ribera d'Alcalà M (eds) Metodi nell'ecologia del plancton marino. Nova Thalassia 11:183-198

Zore-Armanda M (1968) The system of currents in the Adriatic. Sea Rev Gen Fish Coun Medit 34:1-34

Submitted: February 3, 1998; Accepted: August 11, 1998 Proofs received from author(s): June 3,1999 